\title{
Molecular and Genetic Properties of Plasmid R485 Conferring Resistance to Sulphonamides
}

\author{
By J. HOCHMANNOVÁ, ${ }^{*}$ * J. NESVERA, ${ }^{1}$ J. STOKROVÁ ${ }^{2}$ AND \\ J. STRÁNSKÝ' ${ }^{1}$ \\ Czechoslovak Academy of Sciences: Institute of Microbiology ${ }^{1}, C S-14220$ Praha 4 and \\ Institute of Molecular Genetics', CS-166 10 Praha 6, Czechoslovakia
}

(Received 14 May 1981; revised 17 June 1981)

\begin{abstract}
Plasmid R485 carrying a determinant of resistance to sulphonamides was isolated from $\mathrm{rec}^{+}$ and recA Escherichia coli hosts, and its molecular properties were examined and compared with the characteristics of an incompatible plasmid, R6K, a type plasmid of incompatibility group X (IncX). Examination of R485 DNA by electron microscopy revealed monomer, dimer and miniplasmid molecules in preparations isolated from the $\mathrm{rec}^{+}$host, while only monomers were seen in preparations obtained from the recA host. The molecular sizes of the R485 monomers from the $\mathrm{rec}^{+}$and the $\mathrm{recA}$ host were $34.9 \pm 3.7$ and $38.3 \pm$ 0.8 megadaltons (Mdal), respectively. The dimer molecules of R485 (59.7 $\pm 2.9 \mathrm{Mdal}$ ) probably resulted from the recombination between one monomer molecule of normal size and another from which the miniplasmid (11.2 Mdal) was segregated. The $\mathrm{G}+\mathrm{C}$ content of $\mathrm{R} 485$ DNA was $44.3 \mathrm{~mol} \%$. With a minimum copy number of approximately one per $E$. coli chromosome equivalent, plasmid R485 differs conspicuously from the multicopy plasmid $\mathrm{R} 6 \mathrm{~K}$; this finding indicates that the replication of $\mathrm{R} 485$ and $\mathrm{R} 6 \mathrm{~K}$ is differently controlled.

The presence of plasmid $\mathrm{R} 485$ in a cell brought about a reduction of the frequency of conjugative transfer of an IncP plasmid, RP1, and an IncN plasmid, N3A, but it did not affect the transfer of IncW plasmid Sa. Plasmid R485 showed integrative suppression of the expression of a chromosomal temperature-sensitive dnaA mutation, indicating that its replication is independent of the $d n a A$ gene product. The simultaneous presence of incompatible plasmids $\mathrm{R} 485$ and $\mathrm{R} 6 \mathrm{~K}$ in a cell resulted in the elimination of R6K in the absence of selection pressure, while under selective conditions only a decrease in the number of R6K copies was found. Inhibition of growth of $E$. coli E52int6K by plasmid R485 at elevated temperature also indicated the negative effect of $\mathrm{R} 485$ on $\mathrm{R} 6 \mathrm{~K}$ replication.
\end{abstract}

\section{INTRODUCTION}

Plasmid R485, determining resistance to sulphonamides (Hedges et al., 1973), is incompatible with plasmid R6K (Kontomichalou et al., 1970), the type plasmid of incompatibility (Inc) group $\mathrm{X}$, which points to relatedness of these two extrachromosomal elements. On the other hand, some genetic properties of plasmid R485, e.g. its ability to inhibit the fertility of F-like plasmids (Hedges et al., 1973; Gasson \& Willetts, 1977) and to determine the formation of characteristic pili (Bradley, 1978), differ from those of plasmid R6K. While the IncX 'prototype' is well characterized and the mechanism of replication of R6K DNA is known (Kolter et al., 1979), only the above information about plasmid R485, whose IncX status was discussed by Bradley (1980) was available until now.

In this work we provide both basic data on the molecular parameters and replication of R485 DNA and additional information about the genetic properties of plasmid R485, necessary for its overall comparison with plasmid R6K. Further, as the incompatibility of 
related plasmids is functionally associated with the mechanisms of their DNA replication, especially with the control of the number of plasmid copies (Uhlin \& Nordström, 1975; Terawaki \& Kobayashi, 1978), the interactions of plasmids R485 and R6K coexisting in one cell line were also followed. The results obtained may contribute to existing knowledge about the replication of $\mathbf{R}$ plasmids.

\section{METHODS}

Bacterial strains and plasmids. Strains of bacterial hosts for $\mathrm{R}$ plasmids are listed in Table 1; plasmids used are shown in Table 2.

Drugs. The following antibiotics were used: ampicillin (Pentrexyl; Bristol Italiana), chloramphenicol (Spofa, Czechoslovakia), kanamycin and streptomycin (both as sulphates; Medexport, U.S.S.R.), spectinomycin (Trobicin; Upjohn, Belgium), sulphafurazol (Sulfasol; Pliva, Yugoslavia). Abbreviations for these drugs are listed in a footnote to Table 2.

Media. Penassay broth (PAB, Difco) or minimal medium M9 (Adams, 1959) supplemented with appropriate nutrients were used for bacterial growth. Transconjugant selection and $\mathrm{Su}$ resistance determination were carried out on supplemented M9 medium solidified with $1.5 \%$ (w/v) agar (Difco). Resistance to other antibiotics was determined on Tryptose Blood Agar Base (TBAB, Difco) to which the appropriate drug was added; the concentration of sulphafurazol was $1 \mathrm{mg} \mathrm{ml}^{-1}$, and the concentrations of the other antibiotics ranged from 10 to $100 \mu \mathrm{g} \mathrm{ml}^{-1}$.

Plasmid isolation. The procedure of Hansen \& Olsen (1978) was used for the preparation of crude R-plasmid DNA. For analytical investigations, covalently closed circular (CCC) DNA forms of R plasmids were isolated either as described by Katz et al. (1973) or the crude plasmid preparations were purified by ultracentrifugation in a caesium chloride/ethidium bromide $(\mathrm{CsCl} / \mathrm{EB})$ gradient. ColE1 DNA was isolated according to Zasloff et al. (1978).

Agarose gel electrophoresis of plasmid DNA. Plasmid DNA samples were subjected to electrophoresis in the system described by Mickel, Arena \& Bauer (1977), using 0.7\% agarose (Bio-Rad), Ficoll 400000 (250 mg ml-1; Pharmacia) and the vertical slab apparatus Pharmacia GE-4. The molecular size markers were plasmids ColE1 (4.2 Mdal; Staudenbauer, 1978), R6K (26 Mdal; Kontomichalou et al., 1970) and R1drd19 (52 Mdal; Srogl et al., 1977). Electrophoretograms were photographed under short-wavelength ultraviolet light with a Pentacon Six camera through a green GR-1 filter using ORWO NP20 film (ASA 80).

Electron microscopy. Preparations of R485 DNA were spread by the aqueous protein film technique (Davis $e t$ al., 1971) modified as described previously (Šrogl et al., 1977). The molecules were observed in a Jeol 100B electron microscope at a voltage of $60 \mathrm{kV}$ using a $50 \mu \mathrm{m}$ objective aperture. Photographs were taken at a magnification of $\times 10000$.

Contour length measurements of open circular (OC) DNA molecules were made on a Hewlett-Packard Digitizer 9864A from negatives enlarged six- to eightfold. The data were processed by a Hewlett-Packard 9830 calculator with $\pm 0.3 \mu \mathrm{m}$ accuracy. Lengths were converted to molecular weight assuming a linear mass density of $2.08 \pm 0.03 \mathrm{Mdal}_{\mu \mathrm{m}^{-1}}$ (Stüber \& Bujard, 1977).

$G+C$ content of plasmid DNA. This was determined from the buoyant density $(\rho)$ of the DNA in a gradient of $\mathrm{CsCl}$ (Suprapur grade; Merck), essentially as described by Schildkraut et al. (1962). [ $\left.{ }^{15} \mathrm{~N}\right] \mathrm{DNA}$ from Pseudomonas aeruginosa with the density $\rho_{0}=1.7350 \mathrm{~g} \mathrm{~cm}^{-3}$ (acquired from the Institute of Organic Chemistry and Biochemistry, Czechoslovak Academy of Sciences, Praha) was used as a reference standard; this value was determined relative to the correct value of $1.7035 \mathrm{~g} \mathrm{~cm}^{-3}$ for Escherichia coli DNA given by Szybalski \& Szybalski (1971). Centrifugation to equilibrium was performed in a Beckman An-H rotor at 44000 rev. $\min ^{-1}$ and $25^{\circ} \mathrm{C}$ for $24 \mathrm{~h} ; \rho$ was evaluated from the record obtained at $263 \mathrm{~nm}$ by a Beckman photoelectric scanner, and the molar percentage of $\mathrm{G}+\mathrm{C}$ was calculated according to Woodward \& Lebowitz (1980).

Determination of plasmid copy number. A method based on $\mathrm{CsCl} / \mathrm{EB}$ analysis of crude bacterial lysates was used. Cells of $E$. coli J53-1 infected either with plasmid R485 or plasmid R6K $\Delta 1$ were cultured and total DNA was labelled with [ $\left.6-{ }^{3} \mathrm{H}\right]$ thymidine (Institute for Research, Production and Application of Radioisotopes, Praha) as described by Hochmannová \& Nešvera (1982). Lysis of cells, pronase (Calbiochem) digestion and shearing of the lysates were performed according to Womble et al. (1977). Isopycnic centrifugation was done and distribution of radioactivity was followed as previously described (Nešvera et al., 1978). The minimum number of plasmid copies per chromosome equivalent (n.p.c.) was calculated (Hochmannová \& Nešvera, 1982) assuming values of $35 \mathrm{Mdal}$, $21 \mathrm{Mdal}$ and $2500 \mathrm{Mdal}$ for the molecular sizes of R485 (see Results), R6K $\Delta 1$ (Nešvera et al., 1978) and the $E$. coli chromosome (Cooper \& Helmstetter, 1968), respectively. In biplasmid strains R6K n.p.c. was estimated from the degree of $\mathrm{Ap}$ resistance expressed as $\mathrm{LD}_{37}$ (the concentration of $\mathrm{Ap}$ at which only $37 \%$ of the cells formed colonies). The n.p.c. of plasmid R6K $\Delta 1$ in $E$. coli J53-1 determined by the direct radioisotopic method (Hochmannová \& Nešvera, 1982) was used as standard in these estimations. 
Table 1. Bacterial strains

E. coli $\mathrm{K} 12$

derivative

\section{J53-1}

IV-28-1

C600

JC5455

E52

E52int485

E52int6K
Genetic markers*

rec $^{+} ;$pro met nal

recA56; leu thi rpsL

thr leu thi lacY tonA supE

his trp tsx rpsE lac $\Delta X 74$

dnaA thy leu rpsL

dnaA thy leu rpsL sul ${ }^{+}$

dnaA thy leu rpsL bla $^{+}$aphC $C^{+}$
Source

N. Datta, London

J. Hubáček, Praha

A. I. Stepanov, Moscow

N. S. Willetts, Edinburgh

Department of Microbiology, Charles University, Praha

This work

This work

* The symbols for genetic markers are those of Bachmann \& Low (1980) and Novick et al. (1976).

Table 2. Plasmids

\begin{tabular}{|c|c|c|c|}
\hline Plasmid & $\begin{array}{l}\text { Inc } \\
\text { group }\end{array}$ & $\begin{array}{l}\text { Drug resistance } \\
\text { markers* }\end{array}$ & Source \\
\hline R485 & $\mathbf{X}$ & Su† & N. Datta, London \\
\hline R6K & $\mathrm{X}$ & Ap Sm & A. I. Stepanov, Moscow \\
\hline R6K $\Delta 1$ & $\mathrm{X}$ & Ap Sm & Z. Lorkiewicz, Lublin \\
\hline ColE1 & - & - & $\begin{array}{l}\text { Institute of Biophysics, } \\
\text { Czechoslovak Academy of Sciences, Brno }\end{array}$ \\
\hline $\mathrm{R} 1 d r d 19$ & FII & $\mathrm{Ap} \mathrm{Cm} \mathrm{Sm} / \mathrm{Sp} \mathrm{Su}\left(\mathrm{Km}^{s}\right)$ & J. Hubáček, Praha \\
\hline N3A & $\mathbf{N}$ & $\mathrm{Ap} \mathrm{Sm} / \mathrm{Sp} \mathrm{Su}$ & N. Datta, London \\
\hline RP1 & $\mathbf{P}$ & Ap Km Tc & H. Tschäpe, Wernigerode \\
\hline $\mathrm{Sa}$ & W & $\mathrm{Cm} \mathrm{Km} \mathrm{Sm} \mathrm{Su}$ & H. Tschäpe, Wernigerode \\
\hline
\end{tabular}

* Abbreviations: Ap, ampicillin; $\mathrm{Cm}$, chloramphenicol; Km, kanamycin; Sm, streptomycin; Sp, spectinomycin; Su, sulphonamides; Tc, tetracycline.

† A minimal inhibitory concentration of sulphafurazol of $1200 \mu \mathrm{g} \mathrm{ml}^{-1}$ was estimated for $E$. coli J53-1(R485) in liquid M9 medium.

Determination of drug resistance. The minimal inhibitory concentration of $\mathrm{Su}$ was determined by the tube dilution method in liquid medium $\mathrm{M} 9$. The values of $\mathrm{LD}_{37}$ were determined as described by Chiang \& Clowes (1980), except that PAB with Ap $\left(10 \mu \mathrm{g} \mathrm{ml}^{-1}\right)$ was used for growth of bacteria before plating to ensure the maintenance of plasmid R6K in host cells harbouring the incompatible plasmid R485.

Conjugation. This was done as described by Srogl et al. (1977).

Testing of integrative suppression of dnaA ts mutation. Exponential phase cultures of $E$. coli E52 derivatives grown in $\mathrm{PAB}$ at $30^{\circ} \mathrm{C}$ were plated on $\mathrm{TBAB}$. Counts of viable cells at $42{ }^{\circ} \mathrm{C}$ divided by counts at $30^{\circ} \mathrm{C}$ gave the frequency of reversion to temperature resistance. The transfer of chromosomal markers from selected revertants was detected by conjugation at $30^{\circ} \mathrm{C}$ (Srogl et al., 1977); time of mating was prolonged to $140 \mathrm{~min}$.

Incompatibility. This was tested as described by Coetzee et al. (1972).

\section{RESULTS}

\section{Size of plasmid $\mathbf{R} 485$}

The approximate size of plasmid R485 was estimated by agarose gel electrophoresis of crude DNA preparations from $E$. coli J53-1(R485). Based on the results of four independently performed analyses using three plasmid CCC DNAs as standards, a molecular size of $39.9 \pm 2.6 \mathrm{Mdal}$ was obtained for R485 DNA from the inverse linear relation between the logarithms of relative mobility and mass of the CCC plasmid (Meyers et al., 1976). The plot of migration distances versus logarithm of mass of CCC plasmids using the decreasing sigmoid standard curve for plasmid size determination (Nass, 1978; O. Sova, personal communication) yielded the value of $35.9 \pm 2 \cdot 1$ Mdal for R485 DNA.

Preparations of purified R485 DNA isolated from both E. coli J53-1 and E. coli IV-28-1 rec $A$ hosts were observed in an electron microscope. In addition to circular molecules of the 


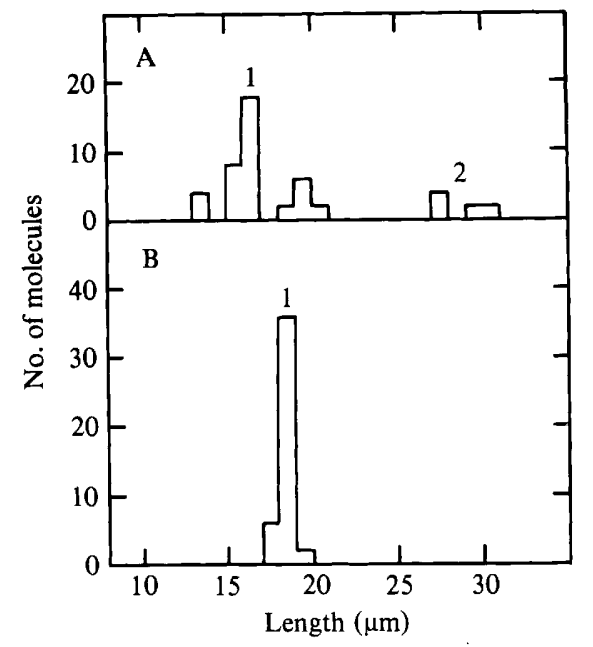

Fig. 1. Histograms showing the dispersion of contour lengths of R485 DNA isolated from two E. coli strains: (A) a rec ${ }^{+}$host, J53-1; (B) a recA host, IV-28-1. 1 and 2 denote the size classes (see also Table 3).

Table 3. Dispersion of sizes of R485 DNA molecules within individual classes

$\begin{array}{lccc}\text { Size class* } & \begin{array}{c}\text { Mean length } \pm \text { S.D. } \\ (\mu \mathrm{m})\end{array} & \begin{array}{c}\text { Molecular size } \pm \text { S.D. } \\ (\text { Mdal })\end{array} & \begin{array}{c}\text { Percentage of total } \\ \text { no. of molecules }\end{array} \\ \text { A1 } & 16.8 \pm 1.8 & 34.9 \pm 3.7 & 81.6 \\ \text { A2 } & 28.7 \pm 1.4 & 59.7 \pm 2.9 & 16.3 \\ \text { Miniplasmid } \dagger & 5.4 & 11.2 & 2.0 \\ \text { B1 } & 18.4 \pm 0.4 & 38.3 \pm 0.8 & 100 \cdot 0\end{array}$

* From Fig. 1; the A prefix denotes molecules from the $\mathrm{rec}^{+}$host and the B prefix those from the recA host.

$\dagger$ Not shown in Fig. 1; from the $\mathrm{rec}^{+}$host only.

Table 4. Buoyant density $(\rho)$ and $G+C$ content of $R$-plasmid $D N A$

$\begin{array}{lcc}\text { DNA } & \rho\left(\mathrm{g} \mathrm{cm}^{-3}\right) & \mathrm{G}+\mathrm{C}(\mathrm{mol} \%) \\ \text { R485 } & 1.6978 & 44.2 \\ & 1.6980 & 44.4 \\ \text { R6K } & 1.6972 & 43.7 \\ & 1.6975^{*} & 43.9 \dagger \\ \text { R6K } \Delta 1 & 1.6973 & 43.7 \\ & 1.6974 & 43.8\end{array}$

*Value determined by Kontomichalou et al. (1970); the published $\rho$ value of $1.704 \mathrm{~g} \mathrm{~cm}^{-3}$ was corrected by subtraction of $0.0065 \mathrm{~g} \mathrm{~cm}^{-3}$ to relate it to the correct value for $E$. coli DNA (Szybalski \& Szybalski, 1971).

$\uparrow$ Calculated according to Woodward \& Lebowitz (1980); by applying the classical equation of Schildkraut $e t$ al. (1962) to the original value of $\rho$, Kontomichalou et al. (1970) obtained $45 \mathrm{~mol} \% \mathrm{G}+\mathrm{C}$.

basic type, molecules of approximately double size and, occasionally, miniplasmids, were seen in R485 preparations obtained from the host with an intact recombination system. Neither dimers nor miniplasmids were observed in samples of R485 DNA isolated from the rec $A$ host. Contour length measurements revealed considerably greater size dispersion of monomer R485 molecules that originated from E. coli J53-1 (Fig. 1). The mean contour lengths of R485 DNA molecules belonging to individual size classes, and the corresponding molecular weights, are summarized in Table 3. 




Fig. 2. $\mathrm{CsCl} / \mathrm{EB}$ centrifugation analysis of $\left[{ }^{3} \mathrm{H}\right] \mathrm{DNA}$ of whole-cell lysates from $E$. coli J53-1(R485) (O) and E. coli J53-1(R6K $\Delta 1)(\mathrm{O})$. CCC DNA peak: fractions 8-12 for R485, fractions 8-13 for R6K $\Delta 1$; (linear + OC) DNA peak: fractions $16-25$ for R485, fractions $17-25$ for R6K $\Delta 1$.

Table 5. Results of fertility inhibition tests

\begin{tabular}{crc} 
& \multicolumn{2}{c}{$\begin{array}{c}\text { Inhibition (transfer inhibition ratio)* } \\
\text { by IncX plasmid: }\end{array}$} \\
\cline { 2 - 3 } Inhibited plasmid & $\mathrm{R} 485$ & $\mathrm{R} 6 \mathrm{~K} \Delta 1$ \\
N3A (IncN) & 4.2 & 42.6 \\
RP1 (IncP) & 88.5 & $200 \cdot 0$ \\
Sa (IncW) & 1.4 & 67.2
\end{tabular}

* Transfer inhibition ratios were obtained by dividing the transfer frequency of inhibited plasmids from cells carrying no other plasmid by their transfer frequency from cells also carrying the indicated inhibiting IncX plasmid (Gasson \& Willetts, 1977).

\section{Base composition of $R 485$ DNA}

$\mathrm{G}+\mathrm{C}$ contents of $\mathrm{R} 485$ and of $\mathrm{R} 6 \mathrm{~K}$ and $\mathrm{R} 6 \mathrm{~K} \Delta 1$ DNAs are presented in Table 4 . No difference in base composition of R485 DNA was observed between preparations isolated from $\mathrm{rec}^{+}$and $\mathrm{recA}$ hosts. Although the polynucleotide chain of R485 DNA is about $40 \%$ longer than that of IncX type plasmid R6K DNA, their base composition differs by $0.5 \%$ only.

\section{Copy number of plasmid $\mathbf{R} 485$}

A conspicuous difference between the quantity of CCC R485 DNA and CCC R6K $\Delta 1$ DNA in the same host was found (Fig. 2). The minimum copy number of plasmid R485 in $E$. coli J53-1 was estimated to be 0.9 per chromosome equivalent (a molecular size of $35 \mathrm{Mdal}$ for R485 was used; see Table 3, size class A1), while the value of 8.9 was calculated for plasmid R6K $\Delta 1$ (both ratios are means from two independent experiments). Thus, in contrast to plasmid $\mathrm{R} 6 \mathrm{~K} \Delta 1$, whose replication is regulated by relaxed control (in a similar manner to the replication of the IncX type plasmid R6K - 11-13 copies per $E$. coli chromosome; Crosa 
Table 6. Results of tests for integration of plasmid R485 into the E. coli chromosome

\begin{tabular}{|c|c|c|c|c|}
\hline \multirow[b]{2}{*}{ Donor* } & \multicolumn{2}{|c|}{ Frequency of recombinants } & \multicolumn{2}{|c|}{$\begin{array}{l}\text { Su-resistant clones } \\
\text { among recombinants }\end{array}$} \\
\hline & $\operatorname{trp} p^{+}$ & his $^{+}$ & $\operatorname{trp} p^{+}$ & his $^{+}$ \\
\hline E52int $485 / 1$ & $1.3 \times 10^{-6}$ & $2 \cdot 1 \times 10^{-7}$ & $149 / 152$ & $10 / 10$ \\
\hline E52int $485 / 2$ & $1.3 \times 10^{-6}$ & $5.3 \times 10^{-7}$ & $42 / 42$ & $19 / 19$ \\
\hline E52(R485) & $<2.9 \times 10^{-7}$ & $<2.9 \times 10^{-7}$ & $0 / 0$ & $0 / 0$ \\
\hline
\end{tabular}

et al., 1975; Chiang \& Clowes, 1980), plasmid R485 seems to replicate under stringent control in E. coli J53-1.

\section{Fertility inhibition}

To test the influence of R485 on the conjugative transfer of IncN, IncP and IncW plasmids, biplasmid derivatives of $E$. coli J53-1 harbouring plasmid R485 together with one of the representative plasmids of the above incompatibility groups were constructed by the selection of transconjugants on M9 agar plates containing appropriate drugs. The frequencies of conjugative transfer of the tested plasmids from the biplasmid strains were compared with those from strains lacking plasmid R485. Plasmid R6K $\Delta 1$ was examined in parallel fertility inhibition experiments (Table 5). The observed inhibition of fertility of IncN, IncP and IncW plasmids by plasmid R6K $\Delta 1$ is in agreement with the results of Pinney \& Smith (1974) and Olsen \& Shipley (1975), proving the inhibition by plasmid R6K of fertility of other plasmids belonging to the incompatibility groups in question. On the other hand, plasmid R485 significantly inhibited only the transfer of plasmid RP1 (IncP). As full compatibility of both IncX plasmids with all the tested IncN, IncP and IncW plasmids was demonstrated (results not shown), wherever a decreased frequency of conjugative transfer of tested plasmids was observed it was undoubtedly due to inhibition of their fertility by IncX plasmids rather than to their elimination.

\section{Integrative suppression}

The IncX type plasmid $\mathrm{R} 6 \mathrm{~K}$ is known to suppress the phenotypic expression of chromosomal temperature-sensitive (ts) dnaA mutation via its integration into the chromosome (Sotomura \& Yoshikawa, 1975). We found that the presence of plasmid R485 in cells of ts mutant E52 also caused a significant increase of reversion frequency to temperature resistance $\left(1.9 \times 10^{-4}\right)$ compared with the spontaneous frequency $\left(3.8 \times 10^{-5}\right)$; a reversion frequency of $1.6 \times 10^{-3}$ was estimated for strain E52(R6K). To demonstrate that the phenotypic reversion of the $d n a A$ ts mutation was really due to the integration of plasmid R485 into the $E$. coli chromosome, selected temperature-resistant revertants (designated E52int485/1 and E52int485/2) were examined for their ability to form trp $^{+}$and his $^{+}$ recombinants by mating with JC5455 as recipient strain. It follows from the results presented in Table 6 that the frequency of $t r p^{+}$recombinants was evidently higher in the mating crosses of both E52int485 strains than in the cross of E52(R485). Moreover, the majority of recombinants of both types exhibited sulphonamide resistance. These results reflect an actual integration of plasmid R485 into the $E$. coli chromosome. The ability of R485 to suppress the dnaA ts mutation via its integration into the chromosome indicates that the replication of plasmid $\mathrm{R} 485$ is independent of the dnaA gene product.

\section{Incompatibility of plasmids $R 485$ and $R 6 K$}

Biplasmid transconjugants (derived from strains J53-1 and C600) harbouring R485 and R6K were obtained by selection on M9 agar plates containing Ap and Su. They were shown 
to lose their ampicillin and streptomycin resistance after growth in PAB without drugs for $6 \mathrm{~h}$ or $18 \mathrm{~h}$. All tested clones (60/60 for each strain) exhibited resistance to sulphonamides only. These results confirmed the incompatibility of plasmids R485 and R6K (Hedges et al., 1973) and showed that in the absence of selection pressure plasmid $\mathrm{R} 6 \mathrm{~K}$ was eliminated preferentially from cells harbouring both incompatible plasmids. Under selective conditions $\mathrm{Ap}, \mathrm{Sm}$ and $\mathrm{Su}$ resistances were preserved in the transconjugants but resistance to $\mathrm{Ap}$ decreased in strains harbouring both plasmids, compared with strains containing only R6K or $\mathrm{R} 6 \mathrm{~K} \Delta 1$. The following $\mathrm{LD}_{37}$ values $\left(\mu \mathrm{g} \mathrm{Ap} \mathrm{ml}{ }^{-1}\right.$ ) for the tested strains were observed: J53-1(R6K $\Delta 1$ ), 540; C600(R6K), 585; J53-1(R485,R6K), 150; C600(R6K,R485), 165. Uhlin \& Nordström (1977) showed that the degree of Ap resistance of $E$. coli strains infected with $\mathrm{R}$ plasmids coding for TEM-1 $\beta$-lactamase was directly proportional to gene dosage. In the case of decreased Ap resistance, the resistance level is thus obviously proportional to the copy number of the $R$ plasmid. The number of $R 6 \mathrm{~K}$ copies in the tested strains could thus be estimated from the straight line constructed by plotting the value of 12 copies per chromosome for R6K $\Delta 1$ as a standard (Hochmannová \& Nešvera, 1982). As the number of 13 copies of plasmid $R 6 \mathrm{~K}$ thus estimated in strain $\mathrm{C} 600(\mathrm{R} 6 \mathrm{~K})$ was in exact agreement with the value reported for the $E$. coli(R6K) system in the literature (Chiang \& Clowes, 1980), the estimates of 3.3 and 3.7 copies of plasmid R6K per chromosome in the respective biplasmid strains seem likely to correspond to the real values. The presence of plasmid R485 in an $E$. coli cell is therefore probably responsible for the decrease in the R6K copy number (to about a quarter of its normal value) even under selective conditions.

\section{Inhibition of growth of strain E52int6K at elevated temperature by plasmid $R 485$}

A temperature-resistant revertant designated E52int6K was obtained and tested for the integration of plasmid R6K into the chromosome by the methods described for strain E52int485. Derivatives E52int6K(R485) and E52int485(R6K) were constructed by selection of transconjugants on $\mathrm{M} 9$ agar plates containing Ap and Su. To ensure the maintenance of incoming incompatible plasmids in these strains, media containing both drugs were used for all subsequent growth and tests. Comparison of growth of biplasmid and monoplasmid strains at $30^{\circ} \mathrm{C}$ and $42^{\circ} \mathrm{C}$ showed that $84 \%$ of E52int $485(\mathrm{R} 6 \mathrm{~K})$ cells survived at $42^{\circ} \mathrm{C}$; this result was not very different from the survival of the temperature-resistant strains E52int485 and E52int6K used as controls. On the other hand, growth of E52int6K(R485) was almost totally inhibited at $42{ }^{\circ} \mathrm{C}$ (only $0.001 \%$ of the cells survived; this value was of the same order as the spontaneous frequency of temperature-resistant revertants of strain E52). These findings indicate the inhibitory effect of plasmid R485 on R6K replication.

\section{DIS CUS SION}

The existence of R485 DNA as molecules of various lengths, namely as dimers, revealed in

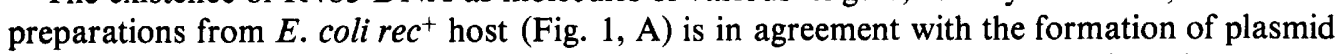
pMB9 multimers observed in an $E$. coli rec ${ }^{+}$host by Bedbrook \& Ausubel (1976), and also shown by these authors for other plasmids harboured by $\mathrm{rec}^{+}$cells. As the $\mathrm{rec} A$ gene product is required for the formation of plasmid multimers (Bedbrook \& Ausubel, 1976), dimers were not detected in preparations of R485 DNA isolated from an E. coli recA host (Fig. 1, B). The mean molecular size of the observed dimer forms of R485 DNA $(59.7 \pm 2.9$ Mdal) is not exactly twice the mean molecular size of an R485 DNA monomer (69.8 Mdal); however, the difference of about $10 \mathrm{Mdal}$ between these two values corresponds to the size of an observed miniplasmid (11.2 Mdal; Table 3). It seems that the monomers of R485 DNA in the rec ${ }^{+}$ host tend to segregate a plasmid of smaller size, as observed in the case of plasmid $222 / \mathrm{R} 3$ (68 Mdal; Nisioka et al., 1969). Recombination of two R485 monomer molecules, one of them being of the basic size ( $35 \mathrm{Mdal}$ ), the other lacking the miniplasmid ( $24 \mathrm{Mdal}$ ) may then result in the formation of the observed dimers. It is of interest that the small segregant plasmid 
from $222 / \mathrm{R} 3$ was about the same size (12 Mdal; Nisioka et al., 1969) as the miniplasmid from R485. Such plasmid(s) may participate in the evolutionary development of R factors. The presented hypothesis explaining the formation of the 'non-exact' dimers of R485 DNA could be tested by analysing the sequence homology between monomers and 'dimers' of R485 DNA. The separation of these two molecular forms from the mixed population generated in an E. coli rec ${ }^{+}$host (Table 3), necessary for such experiments, is in progress.

Differences in the ability of plasmids R485 and R6K to inhibit the conjugative transfer of some F-like plasmids were described by Hedges et al. (1973) and Gasson \& Willetts (1977). Our observations also showed different influences of the incompatible, and thus probably related, plasmids $\mathrm{R} 485$ and $\mathrm{R} 6 \mathrm{~K} \Delta 1$ on the fertility of IncN and IncW plasmids (Table 5). One may thus conclude that the fertility inhibition (Fin) systems of the two IncX plasmids are distinct. As tested IncN, IncP and IncW plasmids varied in their susceptibility to Fin-system(s) of plasmid R485, they very probably differ in the sites at which the Fin-system acts.

The observed 'dominance' of oligocopy plasmid R485 over multicopy plasmid R6K in the incompatibility reaction is in agreement with results showing that some higher-copy-number mutants of IncFII plasmid R1 and IncT plasmid Rts 1 exhibited decreased incompatibility towards plasmids from the IncFII and IncT groups when compared with their respective parent plasmids (Uhlin \& Nordström, 1975; Terawaki \& Kobayashi, 1978). Recently, Molin \& Nordström (1980) demonstrated that the copy number control, incompatibility and regulation of initiation of plasmid DNA replication are different manifestations of the same trans-acting function of plasmid $\mathrm{R} 1$. Our results demonstrating the negative influence of plasmid R485 on the copy number of incompatible plasmid R6K, and its inhibitory action on the growth of E52int6K at elevated temperature, when replication of the $E$. coli chromosome was undoubtedly initiated from the origin(s) of the integrated plasmid (Chandler et al., 1977), indicate that plasmid R485 may code for similar element(s) acting in trans on plasmid R6K.

The results presented in this paper represent a basis for further studies of replication of both plasmids R485 and R6K using mutants with altered numbers of their copies.

The authors thank Dr N. Datta, Dr A. I. Stepanov and Dr N. S. Willetts for providing Escherichia coli strains.

\section{REFERENCES}

Adams, M. H. (1959). Bacteriophages. New York: Interscience.

BaChmanN, B. J. \& Low, K. B. (1980). Linkage map of Escherichia coli $\mathrm{K}-12$. Edition 6. Microbiological Reviews 44, 1-56.

Bedbrook, J. R. \& Ausubel, F. M. (1976). Recombination between bacterial plasmids leading to the formation of plasmid multimers. Cell 9, 707-716.

BRADLEY, D. E. (1978). Determination of very thin pili by the bacterial drug resistance plasmid R485. Plasmid 1, 376-387.

BRADLEY, D. E. (1980). Determination of pili by conjugative bacterial drug resistance plasmids of incompatibility groups $\mathrm{B}, \mathrm{C}, \mathrm{H}, \mathrm{J}, \mathrm{K}, \mathrm{M}, \mathrm{V}$, and $\mathrm{X}$. Journal of Bacteriology 141, 828-837.

Chandler, M., Silver, L. \& Caro, L. (1977). Suppression of an $E$. coli dnaA mutation by the integrated R factor R100.1: origin of chromosome replication during exponential growth. Journal of Bacteriology 131, 421-430.

Chiang, S. J. \& Clowes, R. C. (1980). Intramolecular transposition and inversion in plasmid R6K. Journal of Bacteriology 142, 668-682.

Coetzee, J. N., Datta, N. \& Hedges, R. W. (1972). $\mathrm{R}$ factors from Proteus rettgeri. Journal of General Microbiology 72, 543-552.

Cooper, S. \& Helmstetter, C. E. (1968). Chromosome replication and the division cycle of Escherichia coli B/r. Journal of Molecular Biology 31, 519-540.

Crosa, J. H., Luttropp, L. K., Heffron, F. \& FALKow, S. (1975). Two replication initiation sites on R-plasmid DNA. Molecular and General Genetics 140, 39-50.

Davis, R. W., Simon, M. \& Davidson, N. (1971). Electron microscope heteroduplex methods for mapping regions of base sequence homology in nucleic acids. Methods in Enzymology 21D, 413428.

Gasson, M. J. \& WilletTs, N. S. (1977). Further characterization of the $\mathrm{F}$ fertility inhibition systems of "unusual" Fin ${ }^{+}$plasmids. Journal of Bacteriology 131, 413-420.

HANSEN, J. B. \& OLSEN, R. H. (1978). Isolation of large bacterial plasmids and characterization of the P2 incompatibility group plasmids pMG1 and pMG5. Journal of Bacteriology 135, 227-238. 
Hedges, R. W., Datta, N., Coetzee, J. N. \& Dennison, S. (1973). R factors from Proteus morganii. Journal of General Microbiology 77, 249-259.

Hochmannová, J. \& Nešvera, J. (1982). A rapid and economic method for estimation of the number of plasmid copies in Escherichia coli cells. Folia microbiologica 27 (in the Press).

Katz, L., Kingsbury, D. T. \& Helinski, D. R. (1973). Stimulation by cyclic adenosine monophosphate of plasmid deoxyribonucleic acid replication and catabolic repression of the plasmid deoxyribonucleic acid-protein relaxation complex. Journal of Bacteriology 114, 577-591.

Kolter, R., Inuzuka, M., Figurski, D., Thomas, C., Stalker, D. \& Helinski, D. R. (1979). Plasmid DNA replication: RK2- and R6K-encoded transacting factors and their sites of action. Cold Spring Harbor Symposia on Quantitative Biology 43, 91-97.

Kontomichalou, P., Mitani, M. \& Clowes, R. C. (1970). Circular R-factor molecules controlling penicillinase synthesis, replicating in Escherichia coli under either relaxed or stringent control. Journal of Bacteriology 104, 34-44.

Meyers, J. A., Sanchez, D., Elwell, L. P. \& FALKow, S. (1976). Simple agarose gel electrophoretic method for the identification and characterization of plasmid deoxyribonucleic acid. Journal of Bacteriology 127, 1529-1537.

Mickel, S., ARENA, V., JR \& Bauer, W. (1977). Physical properties and gel electrophoresis behavior of R12-derived plasmid DNAs. Nucleic Acids Research 4, 1465-1482.

Molin, S. \& Nordström, K. (1980). Control of plasmid $\mathrm{R} 1$ replication: functions involved in replication, copy number control, incompatibility and switch-off of replication. Journal of Bacteriology 141, 111-120.

NASS, M. M. K. (1978). A restriction endonuclease cleavage map of mitochondrial DNA from transformed hamster cells. Nucleic Acids Research 5, 403-424.

Nešvera, J., HochmanNová, J. \& STtokrová, J. (1978). Application of R-plasmid DNA's from Escherichia coli minicells in genetic transformation. Folia Microbiologica 23, 278-285.

Nisioka, T., Mitani, M. \& Clowes, R. (1969). Composite circular forms of $\mathbf{R}$ factor deoxyribonucleic acid molecules. Journal of Bacteriology 97, 376-385.

Novick, R. P., Clowes, R. C., Cohen, S. N., Curtiss, R., III, DatTa, N. \& Falkow, S. (1976). Uniform nomenclature for bacterial plasmids: a proposal. Bacteriological Reviews 40, 168-189.

OLSEN, R. H. \& SHIPLEY, P. L. (1975). RP1 properties and fertility inhibition among $P, N, W$, and $X$ incompatibility group plasmids. Journal of Bacteriology 123, 28-35.

Pinney, R. J. \& SMITH, J. T. (1974). Fertility inhibition of an $\mathrm{N}$ group $\mathrm{R}$ factor by a group X R factor, R6K. Journal of General Microbiology 82, 415-418.

Schildkraut, C. L., Marmur, J. \& Doty, P. (1962). Determination of the base composition of deoxyribonucleic acid from its buoyant density in $\mathrm{CsCl}$. Journal of Molecular Biology 4, 430-443.

Sotomura, M. \& Yoshikawa, M. (1975). Reinitiation of chromosome replication in the presence of chloramphenicol under an integratively suppressed state by R6K. Journal of Bacteriology 122, 623628.

Šrogl, M., Hochmannová, J., Nešvera, J., STOKRovÁ, J. \& KLÉGR, M. (1977). Transforming activity of plasmid and chromosomal DNA in Escherichia coli. Folia Microbiologica 22, 353-359.

Staudenbauer, W. L. (1978). Structure and replication of the colicin E1 plasmid. Current Topics in Microbiology and Immunology 83, 93-156.

STÜBER, D. \& BuJARD, H. (1977). Electron microscopy of DNA: determination of absolute molecular weights and linear density. Molecular and General Genetics 154, 299-303.

Szybalski, W. \& Szybalski, E. H. (1971). Equilibrium density gradient centrifugation. In Procedures in Nucleic Acids Research, vol. 2, pp. 311-354. Edited by G. L. Cantoni \& D. R. Davies. New York: Harper \& Row.

TeraWAKI, Y. \& KobaYASHI, Y. (1978). Further characterization of the $R$ plasmid Rts 1 and its mutant pTW2: Replication and incompatibility of the plasmid. Journal of Bacteriology 135, 300-306.

Uhlin, B. E. \& Nordström, K. (1975). Plasmid incompatibility and control of replication: copy mutants of the R-factor R1 in Escherichia coli K-12. Journal of Bacteriology 124, 641-649.

Uhlin, B. E. \& NordSTRÖM, K. (1977). R plasmid gene dosage effects in Escherichia coli $\mathrm{K}-12$ : copy mutants of the R plasmid R1drd-19. Plasmid 1, 1-7.

Womble, D. D., TAYloR, D. P. \& Rownd, R. H. (1977). Method for obtaining more accurate covalently closed circular plasmid-to-chromosome ratios from bacterial lysates by dye-buoyant density centrifugation. Journal of Bacteriology 130, 148153.

WoodwaRd, R. S. \& Lebowitz, J. (1980). A revised equation relating DNA buoyant density to guanine plus cytosine content. Journal of Biochemical and Biophysical Methods 2, 307-309.

ZaslofF, M., Ginder, G. D. \& Felsenfeld, G. (1978). A new method for the purification and identification of covalently closed circular DNA molecules. Nucleic Acids Research 5, 1139-1152. 